\title{
THE QUALITY EVALUATION OF RFN AND PSE PORK LONGISSIMUS LUMBORUM MUSCLE CONSIDERING ITS MICROSTRUCTURE*
}

\author{
Marta Chmiel $^{1 \star}$, Mirosław Słowiński ${ }^{1}$, Sławomir Janakowski² \\ ${ }^{1}$ Department of Technology, ${ }^{2}$ Department of Botany, \\ Warsaw University of Life Sciences - SGGW, Nowoursynowska 166, 02-787 Warszawa, Poland \\ •Corresponding author: marta_chmiel@sggw.pl
}

\begin{abstract}
The aim of this study was to evaluate selected quality attributes of pork longissimus lumborum ( $L L)$ muscle characterized by RFN and PSE occurrence considering its microstructure. The material used in the research was 100 pork meat samples of normal quality (RFN - red, firm, normal, non-exudative) and 100 pork meat samples with PSE defect. The digital images of microstructure of selected meat samples were captured and some quality attributes, including pH level, drip loss, electrical conductivity (EC), water holding capacity (WHC) and CIE $L * a * b *$ parameters, were determined. Based on the findings obtained it was concluded that PSE meat $\left(\mathrm{pH}_{24 \mathrm{~h}} \leq 5.5\right)$ was characterized by higher degradation of muscle fibre structure when compared with the normal meat (RFN). The differences in the microstructure of PSE and RFN meat influenced the colour, electrical conductivity, drip loss and WHC of the meat. The PSE meat was characterized by a significantly lighter color and significantly higher electrical conductivity, along with more intense drip loss and worsened water holding capacity in comparison with RFN meat.
\end{abstract}

Key words: meat quality, microstructure, PSE defect

The occurrence of meat defects has recently received much attention from many scientists and processors as PSE meat has been shown to have poor processing parameters and decreased consumer acceptance (O'Neill et al., 2003). Meat with PSE is a major quality defect facing the entire swine industry. The incidence of PSE meat is, first of all, associated with rapid postmortem glycolysis. It results in fast and abnormal accumulation of excess lactic acid in the muscles. High postmortem acidification rate of muscle tissue and increased carcass temperature (even up to $40^{\circ} \mathrm{C}$ )

*This work was financially supported by Ministry of Science and Higher Education of the Republic of Poland by a grant no. N N312 068739 in 2010-2012. 
lead to changes in muscle proteins, i.e., to their partial denaturation and a loss of cell membrane impermeability (Joo et al., 1999; Huff-Lonergan et al., 2010). Denaturation affects myofibrillar proteins (including myosin) as well as sarcoplasmic proteins (Fischer, $2001 \mathrm{a}, \mathrm{b}$ and 2007). The partial protein denaturation decreases meat water holding capacity (WHC) and leads to meat being lighter accompanied by a higher drip loss and higher electrical conductivity (Torley et al., 2000; Barbut et al., 2008).

Compared with RFN, PSE meat exhibits a lower $\mathrm{pH}$, lighter, unnatural pale colour with varied chromatic values and, in addition, is linked to diminished WHC, elevated drip loss and soft consistency. Consequently, it is not suitable for production of culinary meat and has poor characteristics as a raw material for meat industry. From the technological point of view, processing of the PSE meat negatively affects efficiency of the finished product, juiciness, taste and tenderness. The suitability of PSE meat for the production of culinary meat (especially that of portioned meat) is limited due to the fact that extensive drip is not accepted by the consumers (O'Neill et al., 2003; Barbut et al., 2008).

The aim of this study was to evaluate selected quality attributes of pork longissimus lumborum (LL) muscle characterized by RFN and PSE occurrence considering its microstructure.

\section{Material and methods}

\section{Sampling procedure}

The material for analysis consisted of 200 meat samples of pig longissimus muscles (LL). The samples were excised from a total of 200 right half-carcasses on five occasions for five slaughter days. The weight of slaughtered fatteners (crossbreds of meat pigs with Polish Large White or Polish Landrace) ranged between 95 and $110 \mathrm{~kg}$, and the average weight was $105 \mathrm{~kg}$. The animal slaughtering was conducted in industrial setting in the abattoir of the Meat Plant located in the Świętokrzyskie Province.

\section{Organization and research method \\ pH evaluation}

Approximately 45 min after animal slaughtering, the $\mathrm{pH}_{45}$, values were measured by inserting a spear probe and a temperature sensor of a CP-411 pH-meter (Elmetron, Zabrze, Poland) directly into the analysed muscle at the level of the last thoracic vertebra. The device was calibrated with two buffers ( $\mathrm{pH} 4$ and 7).

\section{Electrical conductivity measurement (EC)}

The electrical conductivity $\left(\mathrm{EC}_{90}\right.$ ) was measured exactly in the same location of the half carcass at 90 min postmortem using Pork Quality Meter (PQM MT-03, Zakład Techniki Mikroprocesorowej EXE, Poznań, Poland) by inserting its probe into the muscle crosswise to the myocytes. The device was calibrated using a 5 and $20 \mathrm{mS}$ measurement standard provided by the producer. 


\section{Carcass cooling}

The carcasses were cooled for $24 \mathrm{~h}$ using the two-stage cooling ( $\mathrm{I}^{\circ}$ ambient temperature: $10^{\circ} \mathrm{C}$, for $1-2 \mathrm{~h}, \mathrm{II}^{\circ}$ ambient temperature: $0-4^{\circ} \mathrm{C}$ for approx. $22 \mathrm{~h}$ until the internal temperature inside the muscle reached no more than $4^{\circ} \mathrm{C}$ ). Then, to evaluate the meat quality, the meat samples ( $m$. longissimus lumborum) were obtained from the carcasses between $1 \mathrm{st}$ and 4th lumbar vertebrae (weighing ca. $1000 \mathrm{~g}$ ) pending another measurements of $\mathrm{pH}_{24 \mathrm{~h}}$ and $\mathrm{EC}_{24 \mathrm{~h}}$.

\section{Drip loss evaluation}

The slice (approx. $100 \mathrm{~g}$ ) was sectioned from each sample which was used for exudate determination. Each slice was weighed and sealed in a polyethylene bag. The samples were stored at $4-6^{\circ} \mathrm{C}$ for $24 \mathrm{~h}$. After this, the bags were opened, the drip was decanted and the meat was reweighed. The amount of exudation was expressed as a percent of the original weight.

\section{CIEL $\boldsymbol{*} \boldsymbol{a} * \boldsymbol{b} *$ evaluation}

The CIE $L * a * b *$ parameters were determined on a freshly cut surface of the remaining muscle sample (after 20-min bloom time at $4-6^{\circ} \mathrm{C}$ ) using a Konica Minolta CM2600d spectrophotometer (Minolta, Osaka, Japan). The following settings were chosen: illuminant $\mathrm{D}_{65}$, observer $10^{\circ}$, aperture $8 \mathrm{~mm}$, calibrated with a white plate ( $L^{*}$ 99.18, $\left.a^{*}-0.07, b^{*}-0.05\right)$. All measurements were analysed in five replicates from which an average was calculated. Using the $a^{*}, b^{*}$ values, the parameters of $C^{*}$ (Chroma) and $\mathrm{h}^{\circ}$ (hue angle) were calculated. Using the $L^{*}, a^{*}, b^{*}$ parameters, the absolute colour difference was estimated (the difference between RFN and PSE meats). The following equation was fitted:

$$
\Delta E=\sqrt{\left(L^{*}{ }_{0}-L^{*}\right)^{2}+\left(a_{0}^{*}-a^{*}\right)^{2}+\left(b^{*}{ }_{0}-b^{*}\right)^{2}}
$$

where:

$\Delta E$ - an absolute colour difference,

$L_{0}^{*}, a_{0}^{*}, b_{0}^{*}-$ means of colour parameters determined for RFN meat (normal meat),

$L^{*}, a^{*}, b^{*}{ }_{1}-$ means of colour parameters determined for PSE meat (defective meat).

The CIE (Commission Internationale de l'Éclairage) standards were employed to analyse the results obtained. Under these criteria, the absolute differences $(\Delta \mathrm{E})$ are classified as discernible by human eye. The $\Delta \mathrm{E}$ values between 0 and 2 are indiscernible, between 2 and 3.5 are discernible by an experienced observer, however, the values above 3.5 are well discernible.

On completing the colour determination of selected meat samples, another slice was cut (approx. $50 \mathrm{~g}$ ) to prepare digital images of microstructure in a Transmission Electron Microscope (TEM). After that, the carcass was deboned and comminuted using a mincing machine Zelmer Diana 886.8 (manufactured by Zelmer, Rzeszów, 
Poland) equipped with $3 \mathrm{~mm}$ plate. The selected quality parameters, such as WHC and total heme pigments were determined at approximately $48 \mathrm{~h}$ post-slaughter.

\section{Water holding capacity (WHC)}

Water holding capacity was determined according to Grau and Hamm (1952) method as modified by Pohja and Niniivaara (1957).

\section{Total heme pigment content}

The total heme pigments content was measured according to a method described by Hornsey (1956). The absorbance was evaluated using a HITACHI-U-1100 reflectance spectrophotometer (Hitachi Corporation, Ltd., Tokyo, Japan).

\section{Meat microstructure}

The digital images of selected meat samples were captured using a Transmission Electron Microscope (TEM, Philips-Morgagni). The collected meat samples were fixed for $2 \mathrm{~h}$ at room temperature in modified Karnovsky's fixative composed of $2 \%$ paraformaldehyde and $2 \%$ glutaraldehyde in $50 \mathrm{mM}$ sodium cacodylate buffer of $\mathrm{pH}$ 7.2. After the pre-fixation process, the samples were rinsed 4 times for 10 minutes with the same buffer at room temperature. Post-fixation was performed with a $1 \%$ solution of osmium tetroxide in $50 \mathrm{mM}$ cacodylate buffer for $2 \mathrm{~h}$ at $4^{\circ} \mathrm{C}$. The samples were then rinsed again 4 times (10 minutes each) with the $50 \mathrm{mM}$ cacodylate buffer at $4^{\circ} \mathrm{C}$. After fixation, the samples were dehydrated in increasing concentration series of ethanol solutions (10 minute baths of aqueous 10, 20, 30, 40, 50, 60, 70, 80, 90 and $100 \%$ ethanol solutions at room temperature). The ethanol was substituted by three changes of propylene oxide for 20 minutes each at room temperature. Next, the dehydrated samples were impregnated with EPON resin in propylene oxide for $2 \mathrm{~h}$ at room temperature in the proportions of 1:3, 1:1 and 3:1. Thereafter they were mounted in pure EPON resin and left for $12 \mathrm{~h}$ in open vessels allowing for evaporation of the remaining propylene oxide. After this, the samples were transferred into flat silicone embedding moulds and the resin was polymerised at $65^{\circ} \mathrm{C}$ for $16 \mathrm{~h}$.

For the purpose of light microscope analysis the semi-thin $(3-\mu \mathrm{m}$ thick) sections were cut with a Reichert Jung (Leica) RM2165 ultramicrotome with crystal-glass knives. The sections were placed in drops of water on microscope slide and dried at $60^{\circ} \mathrm{C}$. To obtain better contrast, the sections were hot stained in aqueous solution of $1 \%$ Crystal Violet for 30 seconds, then rinsed and dried at room temperature. The preparation obtained was used to select an appropriate location on the block to be cut. The sections were examined under an Olympus AX70 "Provis" microscope equipped with an Olympus DP50 digital camera. At interesting strictly defined sites, ultra-thin sections were taken for electron microscopic examinations. The ultra-thin sections (90 nm thick) were cut with a Reichert Joung Ultracut S (Leica) ultramicrotome and diamond knife and mounted on copper grid covered with Formvar ${ }^{\mathrm{TM}}$ film. The sections were stained in saturated ethanol solution of uranyl acetate for $10 \mathrm{~min}$ utes and saturated aqueous solution of lead citrate for $15 \mathrm{~min}$. The preparations were observed with an FEI M268D "Morgagni” Transmission Electron Microscope and 
the digital images (at 14 000x magnification) were captured using an SIS "Morada" digital camera and the SIS iTEM software.

\section{Statistical analysis}

The results obtained were analysed statistically by subjecting all data to analysis of variance (one-way ANOVA). Significant differences between traits were verified by Tukey's test at a significance level of $\alpha=0.05$.

\section{Results}

The classification of raw material based on the borderline values (Table 1) was performed considering the $\mathrm{pH}_{45}$, and $\mathrm{pH}_{24 \mathrm{~h}}$ values.

Table 1. Criteria for quality group classification of pork meat used in the research (Florowski et al., 2008; Pospiech et al., 2011)

\begin{tabular}{l|c|c}
\hline \multirow{2}{*}{ Evaluation criteria } & \multicolumn{2}{|c}{ Meat quality group } \\
\cline { 2 - 3 } & $\begin{array}{c}\text { RFN } \\
\text { normal meat }\end{array}$ & $\begin{array}{c}\text { PSE } \\
\text { exudative meat }\end{array}$ \\
\hline $\mathrm{pH}_{45}$, & $>5.8$ & $\leq 5.8$ \\
$\mathrm{pH}_{24 \mathrm{~h}}$ & $5.5-6.0$ & $\leq 5.5$ \\
\hline
\end{tabular}

Table 2. Selected quality parameters of the pork meat used in the research (averages \pm standard deviation)

\begin{tabular}{|c|c|c|}
\hline \multirow[b]{2}{*}{ Parameters } & \multicolumn{2}{|c|}{ Meat quality group } \\
\hline & $\begin{array}{l}\text { RFN }(n=100) \\
\text { normal meat }\end{array}$ & $\begin{array}{l}\text { PSE }(n=100) \\
\text { exudative mea }\end{array}$ \\
\hline $\mathrm{pH}_{45}$, & $6.1 \pm 0.3$ & $5.7 \pm 0.1$ \\
\hline $\mathrm{pH}_{24 \mathrm{~h}}$ & $5.7 \pm 0.1$ & $5.5 \pm 0.1$ \\
\hline$L^{*}$ & $49.3 \mathrm{a} \pm 1.8$ & $56.0 \mathrm{~b} \pm 2.0$ \\
\hline$a^{*}$ & $2.2 \mathrm{a} \pm 0.4$ & $3.5 \mathrm{~b} \pm 0.3$ \\
\hline$b^{*}$ & $10.7 \mathrm{a} \pm 1.1$ & $12.2 \mathrm{~b} \pm 1.8$ \\
\hline$C^{*}$ & $11.0 \mathrm{a} \pm 1.0$ & $12.8 \mathrm{~b} \pm 1.3$ \\
\hline$h^{\circ}$ & $79.3 \mathrm{a} \pm 4.1$ & $74.8 \mathrm{~b} \pm 5.4$ \\
\hline $\begin{array}{l}\text { Total heme pigment content } \\
\text { (ppm hemin) }\end{array}$ & $58.5 \mathrm{a} \pm 5.2$ & $59.6 \mathrm{a} \pm 6.0$ \\
\hline $\mathrm{EC}_{90^{\prime}}(\mathrm{mS})$ & $3.2 \mathrm{a} \pm 1.1$ & $4.8 \mathrm{~b} \pm 1.2$ \\
\hline $\mathrm{EC}_{24 \mathrm{~h}}(\mathrm{mS})$ & $4.5 \mathrm{a} \pm 2.0$ & $5.6 \mathrm{~b} \pm 2.2$ \\
\hline Drip loss (\%) & $3.9 \mathrm{a} \pm 1.2$ & $5.8 \mathrm{~b} \pm 1.4$ \\
\hline WHC $\left(\mathrm{cm}^{2} / \mathrm{g}\right)$ & $15.9 \mathrm{a} \pm 2.1$ & $23.9 \mathrm{~b} \pm 2.2$ \\
\hline
\end{tabular}

$\mathrm{a}, \mathrm{b}-$ values in rows with different letters differ significantly $(\mathrm{P} \leq 0.05)$. 
As expected, out of 200 porcine longissimus muscles 100 was classified as normal meat (RFN) and 100 as meat with PSE defect. Based on the established classification criteria (Table 1), PSE pork was associated with lower $\mathrm{pH}_{45}$, and $\mathrm{pH}_{24 \mathrm{~h}}$ when compared with RFN pork (Table 2). The statistical analysis was not conducted for the above-mentioned parameters as they constituted the classification criteria.

To determine the differences in the microstructure of PSE and RFN meat the digital images of the selected samples of pork longissimus muscles with normal and PSE quality were taken in a Transmission Electron Microscope (TEM). Normal meat (RFN) was characterized by typical structure of muscle tissue and did not show any distinct destructive changes. The muscle cells exhibited well-preserved structure of sarcomeres, cell nuclei and mitochondria along with well visible regular cross striation. In particular, $\mathrm{Z}$ and $\mathrm{M}$ lines as well as $\mathrm{A}$ and $\mathrm{I}$ bands were finely visualized (Figure 1).

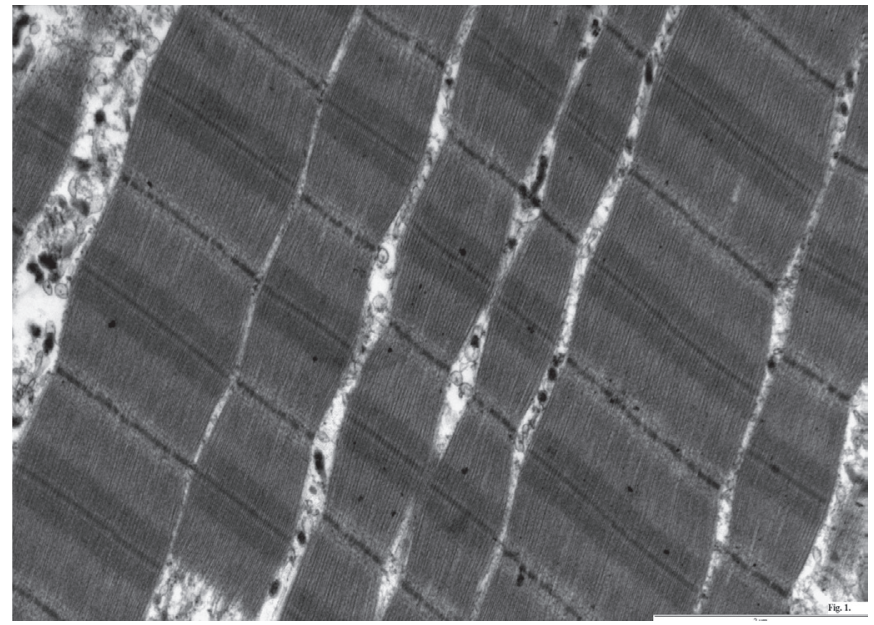

Figure 1. Electron micrograph of RFN meat $(24 \mathrm{~h}$ postmortem, TEM $\times 14000)$

The PSE meat microstructure was different from that of RFN meat. The structure of the muscle fibres showed a higher degree of disintegration. The subtle striation pattern was found within the sarcomere. In addition, the I stria was missing and $\mathrm{Z}$ and $\mathrm{M}$ lines along with the A stria were barely visible. Empty and disintegrating mitochondria were observed. The presence of granule clusters seemed to point to the denaturation of sarcoplasmic proteins and disintegration of sarcoplasmic membrane (Figure 2).

The PSE meat associated with a low $24 \mathrm{~h}$ post-slaughter $\mathrm{pH}\left(\mathrm{pH}_{24 \mathrm{~h}} \leq 5.5\right)$ was characterized by significantly $(\mathrm{P} \leq 0.05)$ higher lightness $\left(L^{*}\right)$, higher values of $a^{*}$ and $b^{*}$ parameters and higher Chroma $\left(C^{*}\right)$ while the hue angle $\left(h^{\circ}\right)$ was lower in comparison with RFN meat (Table 2). It was noted that the differences in lightness $\left(L^{*}\right)$ of the analysed meat quality groups were not attributed to differences $(\mathrm{P}>0.05)$ in the content of total heme pigments which was comparable in PSE and RFN muscles (Table 2). 


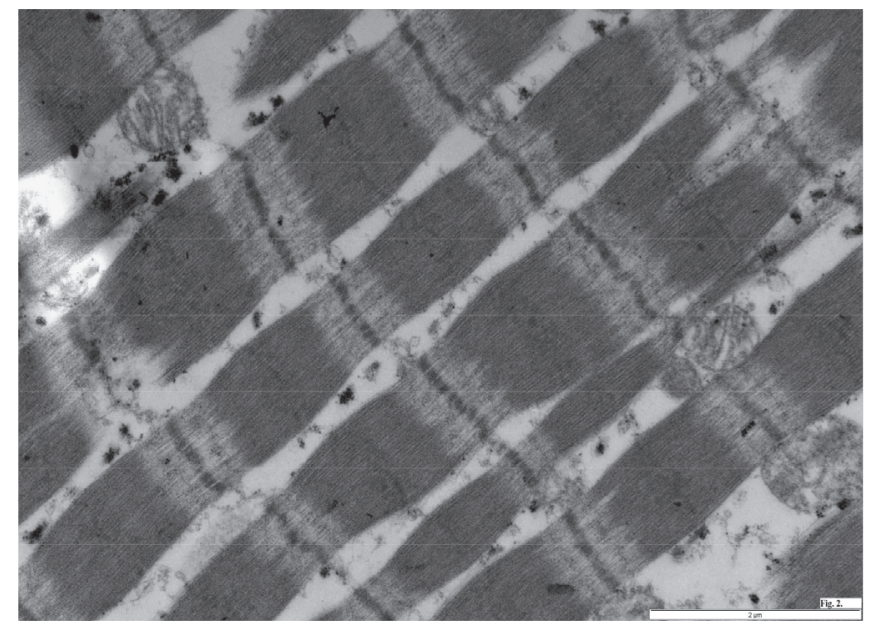

Figure 2. Electron micrograph of meat with PSE defect $(24 \mathrm{~h}$ postmortem, TEM $\times 14$ 000)

The PSE meat was also characterized by significantly $(\mathrm{P} \leq 0.05)$ higher electrical conductivity measured both at $90 \mathrm{~min}\left(\mathrm{EC}_{90}\right)$ and $24 \mathrm{~h}\left(\mathrm{EC}_{24 \mathrm{~h}}\right)$ post-slaughter on the hanging half-carcasses as compared to the normal meat (RFN). The PSE meat was associated with significantly $(\mathrm{P} \leq 0.05)$ higher drip loss and deteriorated water holding capacity when compared with the normal meat (RFN; Table 2).

\section{Discussion}

In the case of PSE meat, i.e. the meat with $\mathrm{pH}_{24 \mathrm{~h}} \leq 5.5$, the rapid muscle tissue acidification immediately after the slaughter leads to changes in the muscle proteins and consequently to their partial denaturation and loss of cell membrane impermeability. As a result, the PSE meat is characterized, among others, by more open and loose structure (Sobina and Kondratowicz, 1999; Laville et al., 2005; SchubertSchoppmeyer et al., 2008). The muscle protein denaturation results in meat being of lighter colour and with lower WHC and, as a consequence, causes an elevated drip loss and higher electrical conductivity (EC). The results obtained were in agreement with the literature findings (Joo et al., 1999; Van Oeckel et al., 1999; Fischer 2001 a, b and 2007; Van Oeckel and Warnants, 2003; Faucitano et al., 2010; Van de Perre et al., 2010 a, b; Lee et al., 2012).

The effect of the meat structure on its colour is predominantly conditioned by the degree of protein denaturation and changes in the spaces between myofilaments dependent on the rate and extent of postmortem $\mathrm{pH}$ drop. These factors exert influence on the transparency parameters of the muscle tissue determining how deep the light and oxygen can penetrate. Consequently, they determine the amount of myoglobin $(\mathrm{Mb})$ being instrumental in pigment formation and relative content of its chemical 
forms. In meat samples with different $\mathrm{pH}$ and structure, it is likely to observe the varying spectrum and rate of colour changes (Feldhusen and Reinhard, 1994; Mancini and Hunt, 2005; Karamucki et al., 2013 a).

The values of chromatic parameters, i.e. the redness $\left(a^{*}\right)$, yellowness $\left(b^{*}\right)$, Chroma $\left(C^{*}\right)$ and hue $\left(h^{\circ}\right)$ are dependent on pigment content in the meat and the amount of pigment illuminated by the light while analysing the samples in addition to being dependent on relative content of chemical forms of myoglobin $(\mathrm{Mb})$ present in raw meat (Feldhusen and Reinhard, 1994; Mancini and Hunt, 2005; Karamucki et al., $2013 \mathrm{a}, \mathrm{b})$. The value of achromatic parameter, being the light, is dependent on the total amount of scattered and absorbed light. The amount of the absorbed light depends, in turn, on the tissue structure as well as the amount of pigments. The higher $a^{*}, b^{*}$ and $C^{*}$ values determined in the current study along with lower hue angle $\left(h^{\circ}\right.$; Table 2) on the colour disc for PSE meat when compared to RFN meat might have resulted from a higher content of oxymyoglobin $(\mathrm{OMb})$ in the tissue layer when penetrated by the light (Karamucki et al., 2013 b). In the present study the measurement of colour parameters was conducted on freshly dissected surface of PSE and RFN meat, after 20 min blooming time, which according to Brewer et al. (2001 and 2006) allows oxygenating purplish red myoglobin $(\mathrm{Mb})$ to form pinkish red oxymyoglobin $(\mathrm{OMb})$. However, more overt and loose structure of PSE meat in comparison to RFN meat resulted in exudative fluid being accumulated on the surface of the meat. The presence of oxymyoglobin $(\mathrm{OMb})$ affected the values of aforementioned chromatic parameters. With a low $\mathrm{pH}$ characteristic of PSE meat, myoglobin has proven to be susceptible to oxygenation and oxidation (Karamucki et al., 2013 b). Karamucki et al. (2013 a, b) and Lindahl et al. (2001) report that oxymyoglobin (OMb) is characterized by large share of red $\left(a^{*}\right)$ and yellow $\left(b^{*}\right)$ colour and high level of Chroma $\left(C^{*}\right)$. Some authors claim that content of particular chemical forms of myoglobin on the surface of meat exerts influence on the lightness of its colour (Lindahl et al., 2006)

The research results of many scientists indicate that there exists the correlation between meat $\mathrm{pH}$ and the lightness $\left(L^{*}\right)$ of its colour. PSE meat is lighter than the normal meat (Joo et al., 1999; Van Oeckel et al., 1999; Fischer, 2001 a, b). A similar trend has also been observed in the current study (Table 2). It is considered that the lighter colour of PSE meat results from denaturation changes occurring in the muscle tissue and destruction of the structure due to a rapid postmortem $\mathrm{pH}$ drop and, as a consequence, the overall effect is light scattering on the meat surface (Wulf and Wise, 1999; Wulf and Page, 2000; Abril et al., 2001; Brewer et al., 2001, 2006; Van Oeckel and Warnants, 2003; Mancini and Hunt, 2005; Warris et al., 2006). It is thought that the most likely causes of these differences in the colour lightness of PSE meat when compared to RFN are shrinking spaces between myofilaments that limit the light penetration and in effect they contribute to the meat being lighter (Joo et al., 1999) and changes in selective light absorption by pigments (Feldhusen and Reinhard, 1994). The absence of significant differences in total heme pigment content (Table 2) may suggest that the elevated amount of oxymyoglobin $(\mathrm{OMb})$ on the surface of analysed PSE meat samples was behind the occurrence of the divergences in values for colour parameters. Karamucki et al. (2013 b) state that the colour of 
PSE meat even with lower pigment content when compared to RFN meat may be characterized by higher redness $\left(a^{*}\right)$, though it can be indiscernible during visual evaluation of the meat colour owing to its higher lightness $\left(L^{*}\right)$.

The absolute colour difference $(\Delta \mathrm{E})$ between meat quality groups calculated on the basis of CIEL*a*b* (Table 2) parameters was 7.0. Using the CIE standards the PSE meat analysed in the present study was characterized by distinct colour difference when compared to the RFN meat.

Having obtained the results one can assume that the colour lightness $\left(L^{*}\right)$ may be used for classification of pork meat into normal meat and that with PSE development. Similar findings were observed by other authors (Lee et al., 2000; Brewer et al., 2001; Van Oeckel and Warnants, 2003; Warris et al., 2006; Faucitano et al., 2010; Di Luca et al., 2011).

Electrical conductivity (EC) is an important meat quality marker being affected by the meat microstructure and which may be considered in its quality classification. The high values for electrical conductivity ( $>8 \mathrm{mS}$ approx. $90 \mathrm{~min}$ after slaughtering) mentioned by authors (Van de Perre et al., 2010 a and 2010 b) may be associated with the damage to cell membranes due to rapid postmortem glycolysis and therefore can serve as an indicator of PSE occurrence. In the current study the PSE meat was characterized by significantly higher EC measured both 90 min and $24 \mathrm{~h}$ after slaughtering when compared to normal meat (Table 2). Simultaneously, the obtained low content of PSE meat with $\mathrm{EC}_{90}$, and $\mathrm{EC}_{24 \mathrm{~h}}>8 \mathrm{mS}$ (11 and 21 units, respectively, data not mentioned) compromises the validity of this measurement as an indicator of PSE meat. Similar results were achieved by e.g. Lee et al. (2000) and Van Oeckel and Warnants (2003). In the present study the results for EC in both analysed meat quality groups were lower than those obtained by above-mentioned authors. Though, analogous findings on EC were obtained by Van de Perre et al. (2010 a). Lee et al. (2000) suggest that the results might be dependent on the type and model of EC measuring device.

The characteristic marker of PSE meat apart from exudative and low $\mathrm{pH}$ is a high drip loss and worsened WHC when compared to RFN meat. The results produced in the current study reflect the above-mentioned dependencies and are in accordance with the literature findings (Lee et al., 2000, 2012; Van Oeckel and Warnants, 2003; Warris et al., 2006; Fischer, 2007; Florowski et al., 2008; Džinić et al., 2009; Di Luca et al., 2011). Irving et al. (1989) and Joo et al. (1999) found that owing to rapid postmortem drop in $\mathrm{pH}$ with the carcass being insufficiently chilled, the denaturation changes in protein muscles and the destruction of cell membrane occur which, in turn, is connected with the changes in its microstructure. Low meat $\mathrm{pH}$ (close to isoelectric point (IP) of protein muscles) exerts influence on the water binding and holding capacity of meat. The closer $\mathrm{pH}$ to isoelectric point (IP) of protein muscles, the lower the water binding and holding capacity of meat. It results in a high drip loss after exsanguination and worsened water holding capacity (Van Oeckel and Warnants, 2003; Florowski et al., 2008; Džinić et al., 2009).

The effect of pork microstructure on the formation of its quality attributes, including colour, is still inconclusive. The PSE meat associated with higher degree of disintegration of myofibre structure when compared to normal meat (RFN) is char- 
acterized by significantly lighter colour $\left(L^{*}\right)$, higher values for $a^{*}, b^{*}$ parameters as well as for Chroma $\left(C^{*}\right)$ attributes whereas lower values for hue angle $\left(h^{\circ}\right)$. Higher electrical conductivity (EC), elevated drip loss and worsened water holding capacity (WHC) of PSE meat in comparison with RFN meat might have been attributed to denaturation changes occurring in the muscle tissue and destruction of the structure due to a rapid postmortem $\mathrm{pH}$ drop in porcine meat. The knowledge of muscle tissue structure can be an auxiliary tool in meat quality evaluation.

\section{References}

A bril M., Campo M.M., Önenc A., S a ñudo C., Albertí P., Negueruela A.L. (2001). Beef colour evolution as a function of ultimate $\mathrm{pH}$. Meat Sci., 58: 69-78.

B arbut S., S ośnicki A.A., Lon ergan S.M., Knapp T., Ci obanu D.C., Gatcliffe L.J., Huff-L on ergan E., Wils on E.W. (2008). Progress in reducing the pale, soft and exudative (PSE) problem in pork and poultry meat. Meat Sci., 79: 46-63.

B rew er M.S., Z h u L.G., B i d n e r B., M e i s in g er D.J., M c K e i th F.K. (2001). Measuring pork color: effects of bloom time, muscle, $\mathrm{pH}$ and relationship to instrumental parameters. Meat Sci., 57: $169-176$.

B rew e r M.S., N ov a k o f s k i J., F re is e K. (2006). Instrumental evaluation of pH effects on ability of pork chops to bloom. Meat Sci., 72: 596-602.

D i Luc a A., Mulle n A.M., Eli a G., D a ve y G., H a mill R.M. (2011). Centrifugal drip is an accessible source for protein indicators of pork ageing and water-holding capacity. Meat Sci., 88: 261-270.

Džinić N., Petrović Lj., Tomović V., Jok anović M. (2009). Influence of seasons on pig halves and meat quality ( $m$. longissimus dorsi) of three-race hybrids. Biotechnol. Anim. Husb., 25: 803-809.

F a uc it a no L., I elo M.C., Ster C., Lo Fieg o D.P., Methot S., S a ucier L. (2010). Shelf life of pork from five different quality classes. Meat Sci., 84: 466-469.

F e $1 \mathrm{~d}$ h u s e n F., R e in h a r d H.J. (1994). Farbveränderungen der Oberfläche von Schweinemuskuatur bei verschieden relative Kühlluftteuchtigkeiten. Fleischwirtschaft, 74: 765-768.

F i s c h e r K. (2001 a). Fleischfehler müssen nicht sein. Fleischwirtschaft, 10: 21-24.

F i s c h e r K. (2001 b). Fleischfehler müssen nicht sein. Fleischwirtschaft, 11: 16-21.

F i s c h e r K. (2007). Drip loss in pork: influencing factors and relation to further meat quality traits. J. Anim. Breed. Genetics, 124, Supl., 12-18.

F 1 or ow sk i T., P i s u la A., R o la M. (2008). Comparison of meatiness and the technological quality of pork from traditional Polish Pulawy breed and its crosses with Polish Large White and Polish Landrace pigs (in Polish). Med. Weter., 64: 673-676.

Gra u R., H a m m R. (1952). Eine einfache Methode zur Bestimmung der Wasserbindung Fleisch. Fleischwirtschaft, 4: 195-297.

H o r s n e y M.C. (1956). The colour of cooked pork. J. Sci. Food Agri., 7, p. 534.

H uff - L o n e rg a n E., Z h a n g W., L o n e r g a n S.M. (2010). Biochemistry of postmortem muscleLessons on mechanisms of meat tenderization. Meat Sci., 86: 184-195.

Irving T.C., S w a t l and H.J., M i $1 \mathrm{~m}$ a n B.M. (1989). X-ray diffraction measurements of myofilament lattice spacing and optical measurements of reflectance and sarcomere length in commercial pork loin. J. Anim. Sci., 67: 152-156.

Jo o S.T., Ka uffman R.G., Kim B.C., Park G.B. (1999). The relationship of sarcoplasmic and myofibrillar protein solubility to colour and water-holding capacity in porcine longissimus muscle. Meat Sci., 52: 291-297.

Karamucki T., Gardzielewska J., Jakubowska M., Rybak K., Garczewska J. (2013 a). The relationship between colour and pH in cold-stored quail breast muscle. Ann. Anim. Sci., 13: 401-413. 
Kara mucki T., Jakubow ska M., Ry barczyk A., Gardzi e lew s ka J. (2013 b). The influence of myoglobin on the colour of minced pork loin. Meat Sci., 94: 234-238.

Laville E., Sayd T., Santé-Lhoutellier V., Morzel M., Labas R., Franck M., Chambon Ch., Monin G. (2005). Characterisation of PSE zones in semimembranosus pig muscle. Meat Sci., 70: 167-172.

Lee S., Norman J.M., Gunasekaran S., van Laack R.L.J.M., Kim B.C., Kauffm a n R.G. (2000). Use of electrical conductivity to predict water-holding capacity in post-rigor pork. Meat Sci., 55: 385-389.

Le e S.H., Cho e J.H., Choi Y.M., Jung K.C., Rhe e M.S., Hong K.C., L e e S.K., Ry u Y.C., $\mathrm{K}$ i m B.C. (2012). The influence of pork quality traits and muscle fiber characteristics on the eating quality of pork from various breeds. Meat Sci., 90: 284-291.

L in d a h 1 G., L un d s trö m K., Tron ber g E. (2001). Contribution of pigment content, myoglobin forms and internal reflectance to the colour of pork loin and ham from pure breed pigs. Meat Sci., 59: $141-151$.

L i n d a h 1 G., K a r l s s o n A.H., L u n d s trö m K., A n d e r s e n H.J. (2006). Significance of storage time on degree of blooming and colour stability of pork loin from different crossbreeds. Meat Sci., 72: 603-612.

Man c in i R.A., Hun t M.C. (2005). Current research in meat color. Meat Sci., 71: 100-121.

O ' N e ill D.J., Ly n ch P.B., Troy D.J., B u c k le y D.J., K e r r y J.P. (2003). Influence of the time of year on the incidence of PSE and DFD in Irish pig meat. Meat Sci., 64: 105-111.

P o h j a N.S., N i in i v a a r F.P. (1957). Die Bestimmung des Wasserbindung des Fleisches mittels der Konstantdrück methode. Fleischwirtschaft, 9: 193-195.

Pospiech E., Iwanowska A., Montowska M. (2011). Animal materials and their quality. Quality of raw meat and its determinants. Meat defects and possibilities to reduce their negative impact on quality (in Polish). In: Mięso - Podstawy Nauki i Technologii, Pisula A., Pospiech E. (eds). Wydawnictwo SGGW, Warsaw, Poland, pp. 231-249.

S chubert-S chop p m e yer A., F i ed l er I., Nürnberg G., Jon a s L., Ender K., Maak S., $\mathrm{R}$ e h feld t C. (2008). Simulation of giant fibre development in biopsy samples from longissimus muscle. Meat Sci., 80: 1297-1303.

S o b in a I., K o n drat ow i c z J. (1999). Differences in the ultra-structure of pigs' normal, PSE and DFD muscles (in Polish). Med. Weter., 55: 542-545.

Torle y P.J., D ' A r c y B.R., Trout G.R. (2000). The effect of ionic strength, polyphosphates type, $\mathrm{pH}$, cooking temperature and preblending on the functional properties of normal and pale, soft, exudative (PSE) pork. Meat Sci., 55: 451-462.

Van de Perre V., Ceustermans A., Leyten J., Geers R. (2010 a). The prevalence of PSE characteristics in pork loin and cooked ham - Effects of season and lairage time. Meat Sci., 86: 391-397.

Van de Perre V., Permentier L., De Bie S., Verbeke G., Geers R. (2010 b). Effect of unloading, lairage, pig handling, stunning and season on $\mathrm{pH}$ of pork. Meat Sci., 86: 931-937.

Van Oeckel M.J., Warnants N. (2003). Variation of the sensory quality within the m. longissimus thoracis et lumborum of PSE and normal pork. Meat Sci., 63: 293-299.

Van O e ckel M.J., Warna n s N., B o u c qué Ch.V. (1999). Measurement and prediction of pork colour. Meat Sci., 52: 347-354.

Warris P.D., B row n S.N., P a ś c i a k P. (2006). The colour of the adductor as a predictor of pork quality in the loin. Meat Sci., 73: 565-569.

W u 1 f D.M., P a g e J.K. (2000). Using measurements of muscle color, pH and electrical impedance to augment the current USDA beef quality grading standards and improve the accuracy and precision of sorting carcasses into palatability groups. J. Anim. Sci., 78: 2595-2607.

Wulf D.M., W is e J.W. (1999). Measuring muscle color on beef carcasses using the L*a*b* color space. J. Anim. Sci., 77: 2418-2427.

Received: 9 X 2013

Accepted: 6 III 2014 